\title{
PENGARUH SOLIDARITAS SOSIAL TERHADAP RESILIENSI BURUH DITENGAH PANDEMI COVID-19
}

\author{
Versanudin Hekmatyar \\ Politeknik Kesejahteraan Sosial Bandung, versahekmatyar@poltekesos.ac.id \\ Nike Vonika \\ Politeknik Kesejahteraan Sosial Bandung, nikevonika@gmail.com
}

\begin{abstract}
The objective of this study is to to show the effect of social solidarity on labor resilience in the midst of the Covid-19 pandemic. By using quantitative approach, data was collected and presented descriptively, as well hypothesis test. Labor with strong social solidarity is expected to have resilience in the face of the Covid-19 pandemic. The results showed that social solidarity had a significant effect on labor resilience in the midst of the Covid-19 pandemic. Social solidarity exists as an effort from the community to minimize the impact of the Covid-19 pandemic so that it can return to its original state. The extreme instability amid the Covid-19 pandemic has forced communities to make concessions to one another and share responsibility for surviving and recovering from the Covid-19 pandemic.
\end{abstract}

Keywords:

Social solidarity, resilience, labor, Covid-19 pandemic

\begin{abstract}
Abstrak
Penelitian ini bertujuan melihat pengaruh solidaritas sosial terhadap resiliensi buruh ditengah pandemi Covid-19. Data dikumpulkan dengan pendekatan kuantitatif dan disajikan secara deskriptif, serta dilakukan uji hipotesis. Buruh dengan solidaritas sosial yang kuat diduga akan memiliki resiliensi dalam menghadapi pandemi Covid-19. Hasil penelitian menunjukan bahwa solidaritas sosial berpengaruh signifikan terhadap resiliensi buruh ditengah pandemi Covid-19. Solidaritas sosial hadir sebagai upaya dari komunitas untuk meminimalisasi dampak pandemi Covid-19 agar dapat kembali ke keadaan semula. Ketidakstabilan ekstrem ditengah pandemi Covid-19 telah memaksa komunitas untuk membuat konsesi satu sama lain dan berbagi tanggung jawab untuk bertahan dan pulih dari pandemi Covid-19.
\end{abstract}

Kata Kunci:

Solidaritas sosial, resiliensi, buruh, pandemi Covid-19

\section{PENDAHULUAN}

Pandemi Covid-19 merupakan darurat kesehatan yang bersifat nyata, dan mengarah pada terjadinya bencana. Kasus pertama Covid-19 diidentifikasi di Kota Wuhan, Cina pada Desember 2019, dan mulai meluas ke berbagai negara. Fakta ini, menimbulkan kekhawatiran, dan meningkat menjadi ancaman sejalan dengan meluasnya penularan Covid-19 ke berbagai negara. Covid-19 adalah penyakit menular yang disebabkan oleh virus corona jenis baru, ditemukan dan diidentifikasi sebagai SARS$\mathrm{CoV}$-2. Virus corona sendiri merupakan keluarga besar virus yang umum terdapat pada hewan dan dapat menyebabkan penyakit pada hewan atau manusia. Pada manusia, beberapa virus corona yang diketahui dan diidentifikasi telah menyebabkan infeksi pernapasan mulai dari flu sampai penyakit yang lebih serius seperti halnya MERS dan SARS, dan virus corona 
yang paling baru diidentifikasi menyebabkan penyakit yang dikenal sebagai Covid-19 (International Labour Organization, 2020).

Pemerintahan berbagai negara selanjutnya menghadapi ancaman besar dalam upaya memerangi pandemi Covid-19, tidak terkecuali Indonesia. Kasus pertama di Indonesia, dikonfirmasi dan disampaikan secara resmi oleh Presiden Republik Indonesia pada, 02 maret 2020 dan terus mengalami peningkatan jumlah penderita sampai hari ini. Berbagai langkah dan paket kebijakan dikeluarkan dalam menghadapi ancaman Covid-19 di Indonesia. Diawali dengan himbauan untuk melakukan sosial distancing, dan physical distancing, dilanjutkan dengan menetapkan status kedaruratan kesehatan nasional pada tanggal 31 maret 2020 melalui Keppres No. 11 tahun 2020 tentang Penetapan Kedaruratan Kesehatan Masyarakat Corona Virus Disease 2019 (Covid-19). Tidak cukup sampai disitu, pada tanggal 13 april 2020 Presiden secara resmi menyatakan kedaruratan bencana nasional. Penetapan ini dinyatakan melalui Keputusan Presiden Republik Indonesia Nomor 12 Tahun 2020 tentang Penetapan Bencana Non-Alam Penyebaran Corona Virus Disease 2019 (Covid-19) Sebagai Bencana Nasional dan memberlakukan Pembatasan Sosial Berskala Besar atau yang biasa disebut PSBB. Pemberlakuan PSBB didasarkan pada dikeluarkannya Peraturan Pemerintah Nomor 21 Tahun 2020 tentang Pembatasan Sosial Berskala Besar. PSBB adalah pembatasan kegiatan tertentu penduduk dalam suatu wilayah yang diduga terinfeksi Covid-19 sedemikian rupa untuk mencegah kemungkinan penyebaran Covid-19. PSBB paling sedikit meliputi; 1) peliburan sekolah dan tempat kerja; 2) pembatasan kegiatan keagamaan; dan/atau 3) pembatasan kegiatan di tempat atau fasilitas umum. Dengan ditetapkannya sebagai darurat bencana nasional, maka selanjutnya leading sector berada ditangan BNPB, yang sekaligus memimpin gugus tugas penangan Covid-19 untuk menangani kedaruratan bencana dengan skala nasional.

Pengertian bencana menurut Undangundang No. 24 Tahun 2007 pasal 1 ayat 1 tentang Penanggulangan Bencana didefinisikan sebagai peristiwa atau rangkaian peristiwa yang mengancam dan mengganggu kehidupan dan penghidupan masyarakat yang disebabkan oleh faktor alam, faktor non alam, dan faktor manusia sehingga mengakibatkan timbulnya korban jiwa, kerusakan lingkungan, kerugian harta benda, dan dampak psikologis. Selanjutnya, pada pasal 1 ayat 3 menyebutkan bencana nonalam adalah bencana yang diakibatkan oleh peristiwa atau rangkaian peristiwa nonalam yang antara lain berupa gagal teknologi, gagal modernisasi, epidemi, dan wabah penyakit. Disebut "serangkaian" peristiwa karena bencana terjadi tidak begitu saja, terdapat sebab atau tanda-tanda, kemudian peristiwa bencana dan diakhiri dengan dampak atau akibat yang ditimbulkan dari sebuah bencana tersebut. Sehingga, kesiapan bencana harus melibatkan lebih dari layanan darurat yang efektif dan efisien, sekaligus memiliki respons cepat selama fase akut dari peristiwa bencana. Selain krisis kesehatan yang sedang berlangsung, ada kekhawatiran dalam mempertahankan stabilitas ekonomi ditengah penyebaran pandemi Covid-19.

Fakta bahwa ketergantungan sosial, teknologi, dan ekonomi, serta tren migrasi sebagai ciri masyarakat modern menjadi 
potensi untuk menjadikan bencana pandemi Covid-19 lebih besar dan memberikan dampak yang lebih luas. Pada akhirnya, pandemi Covid-19 tidak hanya mengakibatkan masalah bagi kesehatan masyarakat, tetapi juga membawa implikasi dan berdampak pada sektor ekonomi yang lebih luas. Banyak negara menghadapi tantangan berat, tidak terkecuali Indonesia.

Indonesia harus memiliki strategi khusus untuk mengatasi hal tersebut, sehingga dampak dari bencana pandemi Covid-19 dapat diminimalisasi tanpa menimbulkan dampak yang signifikan bagi masyarakat. Langkah-langkah untuk menyikapi pandemi Covid-19 ini juga berdampak langsung terhadap pasokan produksi barang dan jasa, permintaan konsumsi dan sekaligus dunia kerja. Menurut Ghafur \& Gazali, (2012) bencana selalu terkait dengan tingkat kerentanan seseorang atau lingkungan, kerentananlah yang menyebabkan sebuah bahaya (hazard) menjadi bencana (disaster). Bencana terjadi apabila seseorang atau komunitas memiliki kerentanan dan tidak memiliki kemampuan adaptasi, sehingga bahaya yang datang menjadi ancaman untuk komunitas tersebut. Dampak kerugian yang ditimbulkan dari terjadinya bencana membuat suatu komunitas mengalami kerentanan. Seperti yang terjadi pada Buruh ditengah Pandemi Covid-19. Tentu, komunitas tidak mengharapkan dampak negatif yang besar seperti krisis ekonomi akibat hilangnya sumber pendapatan mereka. Pengurangan dampak dari bencana dapat dilakukan, salah satunya adalah meningkatkan resiliensi komunitas.

Menurut Dombrowsky, (1983) resiliensi komunitas adalah kemampuan masyarakat untuk membangun, mempertahankan, atau mendapatkan kembali tingkat kapasitas komunitas yang diharapkan dalam menghadapi kesulitan dan tantangan positif. Van Breda, (2001) menjelaskan bahwa upaya meningkatkan kapasitas negara untuk bertahan dan pulih dari keadaan darurat bencana, diperlukan langkah yang terkoordinasi dan kooperatif. Secara global, ada peningkatan pengakuan tentang pentingnya pelibatan masyarakat secara berkelanjutan yang memfasilitasi kesiapsiagaan sebelum bencana dan memungkinkan pemulihan yang efisien selama, dan setelah kejadian. Arbon et al., (2013) menegaskan bahwa bencana memberikan pemicu bagi tindakan sosial yang mungkin tidak hadir dalam kondisi non-bencana, dan dalam hal ini, solidaritas sosial memberikan dasar aksi. Bagi Dombrowsky, (1983) solidaritas sosial akan memiliki makna yang lebih dalam ketika komunitas menghadapi musuh kolektif, sehingga memberi perasaan persatuan, bantuan, dan kohesi dalam keadaan sulit. Solidaritas sosial tumbuh di level individu dan komunitas sesuai kearifan lokal masingmasing. Nilai-nilai komunitas dan semangat solidaritas sosial selanjutnya menjadi katalisator dalam membangun kolektivitas.

Solidaritas sosial sendiri merupakan tema sentral yang menjadi karya utama Durkheim sebagai fakta sosial dan sumber moral untuk membentuk tatanan sosial di tengah masyarakat. Bagi Durkheim, ketidakstabilan ekstrem memaksa masyarakat untuk membentuk konsesi satu sama lain dan berbagi tanggung jawab, yang disebut solidaritas sosial, untuk mengembalikan situasi normal. Hal ini menurut Johnson, (1986) digunakan untuk menganalisa pengaruh (atau fungsi) kompleksitas dan spesialisasi pembagian 
kerja dalam struktur sosial dan perubahanperubahan yang diakibatkannya dalam bentuk-bentuk pokok solidaritas sosial. Secara singkat, perubahan pembagian kerja atau spesialisasi meningkatkan perubahan dalam struktur sosial dari solidaritas mekanik ke solidaritas organik. Solidaritas mekanik, didasarkan pada kepercayaan bersama, cita-cita, dan komitmen moral. Solidaritas mekanik menggambarkan bahwa individu-individu yang memiliki kepercayaan dan cita-cita yang sama sudah seharusnya bersatu dibawah kesadaran kolektif.

Secara singkat, solidaritas menunjuk pada suatu keadaan hubungan antara individu dan/atau kelompok yang didasarkan pada perasaan moral dan kepercayaan yang dianut bersama yang diperkuat oleh pengalaman emosional bersama (Johnson, 1986). Solidaritas sosial merupakan kekuatan persatuan internal dari suatu kelompok dan suatu keadaan hubungan antara individu dan kelompok didasarkan pada perasaan moral dan kepercayaan yang dianut bersama serta diperkuat pengalaman emosional bersama (Nasution, 2009).

Meskipun istilah "solidaritas" adalah konsepsi yang sering disalahgunakan, tampaknya dapat disesuaikan dalam konteks ini untuk menggambarkan pola perilaku yang memberi orang perasaan persatuan, bantuan, dan kohesi dalam keadaan sulit khususnya didalam masyarakat modern dimana spesialisasi terjadi. Demikian pada penelitian ini akan lebih banyak merujuk pada apa yang disebut Durkheim sebagai solidaritas organik. Meskipun demikian, perlu untuk memilih definisi yang mempertahankan konten asli dalam tradisi konsepsi solidaritas organik Durkheim.
Penting untuk diperhatikan bahwa solidaritas bukanlah fenomena terpadu yang statis dan tidak berubah. Solidaritas mengambil bagian dari elemen moral, politik, dan performa yang didukung dan diperkuat oleh konteks kerjasama, infrastruktur organisasi, dan kerangka kelembagaan yang secara bersama-sama menciptakan ketergantungan (Morgan \& Pulignano, 2020).

Solidaritas sosial hadir sebagai upaya dari komunitas untuk meminimalisasi dampak bencana agar dapat kembali ke keadaan semula. Kembalinya komunitas pada keadaan semula dapat dinilai sebagai ketahanan komunitas dalam mengatasi bencana. Mereka harus menghasilkan pola tindakan di bawah tekanan untuk sukses selama situasi yang mengancam. Setiap strategi untuk aksi juga menyiratkan jenis solidaritas yang berbeda. Tumbuhnya solidaritas sosial di komunitas berhubungan erat dengan karakter yang dimiliki komunitas secara lokal. Selanjutnya, ketahanan komunitas dapat digunakan sebagai petunjuk untuk melihat resiliensi komunitas dalam menghadapi bencana. Resiliensi komunitas diperlukan agar komunitas dapat menjalankan fungsinya kembali pasca bencana terjadi.

Kesiapan bencana penting untuk melibatkan lebih dari layanan darurat yang efektif dan efisien, lebih dari itu harus memiliki respons cepat selama fase akut dari peristiwa bencana. Selain krisis kesehatan yang sedang berlangsung, ada kekhawatiran dalam mempertahankan stabilitas ekonomi ditengah penyebaran pandemi Covid-19. Fakta bahwa ketergantungan sosial, teknologi, dan ekonomi, serta tren migrasi sebagai ciri masyarakat modern menjadi potensi untuk menjadikan bencana pandemi 
Covid-19 lebih besar sekaligus memberikan dampak yang lebih luas. Dampak kerugian yang ditimbulkan dari terjadinya bencana membuat suatu komunitas mengalami kerentanan. Seperti yang terjadi pada buruh ditengah pandemi Covid-19. Fakta ini menuntut buruh secara kolektif mengembangkan solidaritas sosial untuk meminimalisir terjadinya kerentanan akibat pandemi Covid-19 yang sedang berlangsung. Berdasarkan pemaparan tersebut, artikel ini berusaha mengidentifikasi bentuk solidaritas sosial pada Buruh ditengah Pandemi Covid-19.

\section{METODE}

Penelitian yang mendasari artikel ini dilakukan untuk menguji pengaruh solidaritas sosial terhadap resiliensi buruh ditengah pandemi Covid-19. Secara sederhana, kerangka pemikiran dapat dilihat pada gambar 1 .

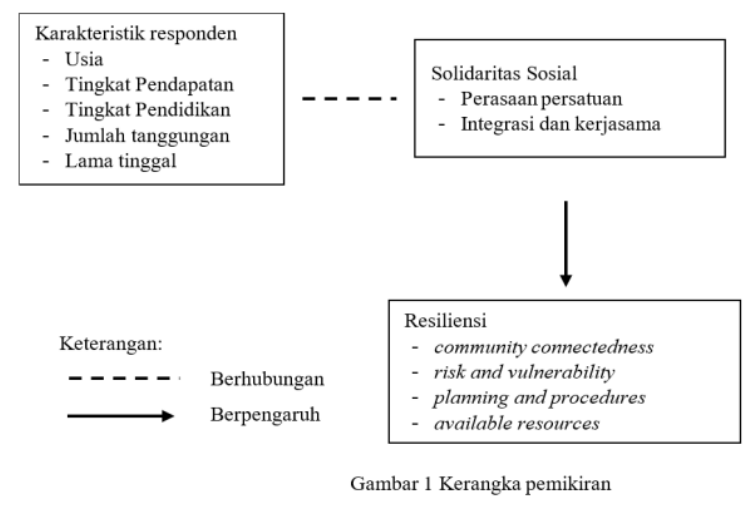

Pendekatan kuantitatif digunakan dan dilakukan dengan survei yang didukung dengan menggunakan data kualitatif. Penelitian survei menitikberatkan pada penelitian relasional, yakni hubungan variabel-variabel, sehingga secara langsung atau tidak langsung hipotesa penelitian senantiasa dipertanyakan (Singarimbun \& Effendi, 1989). Jenis data yang digunakan dalam penelitian ini adalah data primer dan data sekunder. Data primer dikumpulkan melalui survei dengan menggunakan kuesioner, dan wawancara. Pertanyaan dari kuesioner kepada responden bertujuan untuk mendapatkan data secara kuantitatif terkait pengaruh solidaritas sosial terhadap resiliensi buruh ditengah pandemi Covid-19.

Sedangkan, data kualitatif diperoleh dari hasil wawancara bersama informan dengan menggunakan panduan pertanyaan yang telah disusun sebelumnya. Kemudian, untuk data sekunder diperoleh dari rilis yang dikeluarkan FBLP, serta data lain yang didapatkan dengan penelitan kepustakaan melalui penelaahan buku-buku yang sesuai dengan topik, jurnal ilmiah yang berguna secara teoritis dan dokumen lainya yang berhubungan dengan masalah penelitian.

Subjek yang menjadi populasi dalam penelitian ini adalah buruh anggota Federasi Buruh Lintas Pabrik (FBLP) yang mengalami pemutusan hubungan kerja (PHK) ditengah situasi pandemi Covid-19. Selanjutnya untuk melakukan survei, sampel ditentukan agar dapat digunakan untuk mewakili populasi dengan mempertimbangkan faktor-faktor sebagai berikut; (1) derajat keseragaman; (2) presisi yang dikehendaki dalam penelitian; (3) rencana analisa; (4) tenaga, biaya, dan waktu (Singarimbun \& Effendi, 1989).

Untuk menentukan jumlah sampel yang representatif, langkah-langkah yang dilakukan pertama, mengkaji sifat atau karakteristik populasinya, dan kedua, baru menentukan ukuran sampel. Secara umum, tidak ada peraturan yang baku dalam prinsip-prinsip penentuan ukuran besaran sampel yang digunakan dalam sebuah penelitian. Menurut Gay et al., (2012) secara umum, ukuran sampel minimum tergantung pada jenis penelitian yang dilakukan sebagai pedoman ukuran sampel untuk penelitian 
korelasional, kausal-komparatif, dan penelitian eksperimental yang benar. Atas dasar tersebut, besar sampel yang digunakan pada penelitian ini adalah 47 responden. Hal ini dengan mempertimbangkan derajat keseragaman populasi yang cenderung homogen, yaitu sebagai buruh anggota Federasi Buruh Lintas Pabrik (FBLP) yang mengalami pemutusan hubungan kerja (PHK) ditengah situasi pandemi Covid-19.

Teknik sampling yang digunakan dalam penelitian ini adalah simple random sampling (acak sederhana). Simple random sampling adalah proses pemilihan sampel sedemikian rupa sehingga semua individu dalam populasi yang ditentukan memiliki kesempatan yang sama dan independen untuk dipilih sebagai sampel. Dengan kata lain, setiap individu memiliki probabilitas yang sama untuk dipilih, dan pemilihan satu individu sama sekali tidak memengaruhi pemilihan pada individu lain.

Data kuantitatif diolah dan dianalisis menggunakan sofware Microsoft Excell 2019 dan IBM SPSS Statistics 24, dengan unit analisis yang diambil adalah individu yang berjumlah 47 orang responden. Kemudian, tabel frekuensi disusun untuk melihat data awal responden untuk masingmasing variabel secara tunggal menggunakan sofware Microsoft Excell 2019 dan IBM SPSS Statistics 24. Selanjutnya, digunakan uji korelasi untuk melihat hubungan antara modal sosial dan sense of community dengan solidaritas sosial, serta digunakan uji regresi untuk melihat pengaruh solidaritas sosial terhadap resiliensi buruh.

Sedangkan, data kualitatif dianalisis melalui tiga tahap yaitu reduksi data, penyajian data, dan verifikasi. Pertama ialah proses reduksi data dimulai dari proses pemilihan, penyederhanaan, abstraksi, hingga transformasi data hasil wawancara dan studi dokumen. Tujuan dari reduksi data ini ialah untuk mempertajam, menggolongkan, mengarahkan, dan membuang data yang tidak perlu. Kedua ialah penyajian data yang berupa menyusun segala informasi dan data yang diperoleh menjadi serangkaian kata-kata yang mudah dibaca ke dalam sebuah laporan. Verifikasi adalah langkah terakhir yang merupakan penarikan kesimpulan dari hasil yang telah diolah pada tahap reduksi. Guna mengurangi kemungkinan salah interpretasi, digunakan beragam prosedur yang disebut triangulasi. Dalam penelitian ini, triangulasi dilakukan untuk mengklarifikasi atau membandingkan data dan informasi yang berasal dari sumber informasi dan cara pengumpulan data yang berbeda.

\section{HASIL PENELITIAN}

\section{Konteks Federasi Buruh Lintas Pabrik}

Federasi Buruh Lintas Pabrik sebelumnya bernama Forum Buruh Lintas Pabrik berdiri pada 5 Juni 2009. Federasi Buruh Lintas Pabrik atau yang lebih dikenal dengan FBLP aktif melakukan pengorganisiran buruh dari lintas pabrik dan lintas hunian buruh, khususnya yang berlokasi di sekitar Kawasan Berikat Nusantara (KBN) Cakung. Sebagai serikat buruh, FBLP bersama serikat buruh lain konsisten memperjuangkan kesejahteraan buruh.

Perjuangan FBLP berfokus pada kejelasan kontrak kerja, kepastian hak reproduksi pada buruh perempuan, dan menentang bentuk-bentuk intimidasi serta diskriminasi di lingkungan kerja. Bagi FBLP, kesejahteraan dan kesetaraan adalah bagian penting perjuangan, sekaligus 
menjadi kekuatan untuk memenangkan demokrasi yang pro-rakyat.

Selain aktif dalam gerakan buruh, FBLP juga aktif dalam penguatan kapasitas anggotanya. Penguatan kapasitas anggota, dilakukan FBLP sebagai upaya membangun dan mendorong alat-alat perjuangan. Setiap anggota didorong maju dan berkembang, agar mampu membela dan memperjuangkan haknya dan orang lain, agar mampu menjadi pimpinan, agar meningkat pengetahuan dan bisa menyampaikan gagasan, bisa mengembangkan hobi dan bakat, dan lain sebagainya agar semakin kuat organisasi sekaligus berkembang masing-masing pribadi, agar semua semakin kuat berjuang dengan rasa nyaman dan bahagia.

FBLP mendirikan radio komunitas pada tahun 2012 untuk pusat informasi dan pengetahuan, yaitu Radio Buruh Perempuan Marsinah FM. Radio ini juga menjadi salah satu alat bagi FBLP untuk melawan ketakutan-ketakutan dengan melibatkan buruh perempuan supaya bersuara dengan menjadi penyiar dan pengelola rubrik di Marsinah FM.

FBLP juga mendirikan dan mengembangkan koperasi buruh, yang membantu buruh menghadapi berbagai desakan kebutuhan hidup. Koperasi ini bernama Koperasi Sejahtera FBLP berdiri tahun 2014 lalu. Koperasi ini beranggotakan buruh dari berbagai pabrik. Selain menyatakan perang terhadap sistem pinjaman ala rentenir, Koperasi Sejahtera FBLP juga menyelenggarakan pendidikanpendidikan secara regular, untuk membekali pengurus dan anggota, terkait ekonomi rumah tangga dan supaya sanggup membedakan mana kebutuhan dan keinginan.
Federasi Buruh Lintas pabrik (FBLP) juga menggagas adanya Sekolah Buruh Perempuan (SBP), yaitu satu methode pembelajaran untuk buruh perempuan dalam rangka meningkatkan kapasitas dan kepemimpinan buruh perempuan. Membongkar makna kerja dan jam kerja bagi buruh perempuan, juga memahami konsep gender. Dengan harapan semakin banyak buruh perempuan yang terlibat aktif dalam perjuangan dan menempati posisi strategis organisasi dengan kapasitas dan kualitas yang memadai, sekolah Buruh Perempuan diresmikan pada tahun 2016.

Meskipun demikian, sejak pandemi Covid-19 dan dengan ditetapkannya pembatasan sosial berskala besar (PSBB), FBLP sebagai serikat buruh menghadapi tantangan yang sulit. Mereka menghadapi ketidakpastian yang sering memenuhi kepentingan modal, dan pasar tenaga kerja yang ditentukan oleh tingkat pengangguran yang tinggi, pekerjaan tidak tetap, dan informalitas. Melihat ketidakpastian tersebut, tampaknya FBLP saat ini kurang memiliki alternatif strategis selain membangun solidaritas lintas batas, meskipun mungkin sulit bagi mereka untuk kembali ke jalur kerja sama.

\section{Karakteristik Responden}

Karakteristik responden yang dimaksud dalam penelitian ini adalah karakteristik individu yang mempengaruhi solidaritas sosial, terdiri dari jenis kelamin, umur, pendidikan terakhir, lama tinggal di lokasi penelitian, jumlah tanggungan dan jumlah pendapatan. Responden dalam penelitian ini berjumlah 47 orang anggota serikat buruh FBLP yang dipilih secara acak sederhana (simple random sampling), terdiri dari 34 $(72,34 \%)$ perempuan dan $13(27,66 \%)$ laki- 
laki, dengan lebih dari setengahnya memiliki pendidikan terakhir dibawah SMA. Pendidikan terakhir merupakan jenjang pendidikan formal terakhir yang ditempuh oleh responden sampai penelitian ini dilaksanakan. Secara lengkap, pendidikan formal terakhir yang ditempuh oleh anggota serikat buruh FBLP yang menjadi responden secara lengkap dapat dilihat pada tabel 1 dibawah ini.

Tabel 1 Distribusi tingkat pendidikan dan jenis kelamin responden

\begin{tabular}{lcrrrrr}
\hline \multirow{2}{*}{$\begin{array}{l}\text { Tingkat } \\
\text { Pendidikan }\end{array}$} & \multicolumn{2}{c}{ Laki-laki } & \multicolumn{2}{c}{ Perempuan } & \multicolumn{2}{c}{ Total } \\
\cline { 2 - 7 } & $\mathrm{n}$ & \multicolumn{1}{c}{$\%$} & $\mathrm{n}$ & \multicolumn{1}{c}{$\%$} & $\mathrm{n}$ & $\%$ \\
\hline SD/Sederajat & 4 & 8,51 & 2 & 4,26 & 6 & 12,77 \\
SMP/Sederajat & 5 & 10,64 & 9 & 19,15 & 14 & 29,79 \\
SMA/Sederajat & 4 & 8,51 & 20 & 42,55 & 24 & 51,06 \\
Sarjana/Sederajat & 0 & 0,00 & 3 & 6,38 & 3 & 6,38 \\
\hline Total & 13 & 27,66 & 34 & 72,34 & 47 & 100,00 \\
\hline
\end{tabular}

Secara umum, responden merupakan buruh yang bekerja di sekitar Kawasan Berikat Nusantara (KBN) Cakung dengan pendapatan rata-rata sebelum pandemi Covid-19 berkisar antara Rp. 3.546.043 Rp. 4.200.000. Kemudian sejak pandemi Covid-19 dan dengan ditetapkannya pembatasan sosial berskala besar (PSBB) menjadikan pendapatan rata-rata buruh berkisar antara Rp. 1.693.617 - Rp. 2.500.000. Hal ini dikarenakan terdapat pengaturan work from home (WFH) yang mengharuskan kerja dilakukan dengan adanya shift (bergantian), bahkan diantaranya harus benar-benar tidak bekerja karena dirumahkan tanpa kejelasan status dan adanya pemutusan hubungan kerja.

\section{Solidaritas Sosial Buruh Anggota FBLP}

Sejak pandemi Covid-19 dan dengan ditetapkannya pembatasan sosial berskala besar (PSBB), buruh yang bekerja di Kawasan Berikat Nusantara (KBN) Cakung menghadapai ketidakpastian dengan adanya pembatasan aktivitas produksi di pabrik. Hal ini membawa konsekuensi pada sumber pendapatan utama buruh. Status pembatasan sosial berskala besar (PSBB) secara langsung telah menggoncang sumber penghidupan para buruh pabrik. Kondisi ini pada akhirnya membuat buruh harus bergantung pada sesama buruh untuk bersolidaritas memenuhi kebutuhan dasar harian. Alfirdaus, (2015) menyatakan solidaritas sosial sebagai keterikatan antara individu dalam masyarakat, menjadi sumber moralitas konsensual, dan cara masyarakat untuk mengejar ketertiban sosial. Solidaritas sosial pada penelitian ini dilihat melalui dua aspek yaitu, perasaan persatuan, dan integrasi atau kerjasama.

Pertama, perasaan persatuan diukur dengan melihat kedekatan dan kebanggaan sebagai anggota FBLP, serta nilai-nilai yang sama dengan FBLP. Secara lengkap dapat dilihat pada tabel 2 dibawah ini.

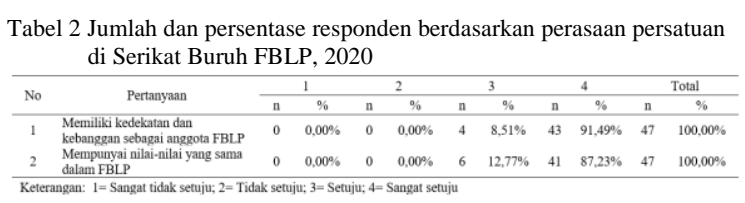

Berdasarkan tabel 2, terlihat bahwa responden memiliki kedekatan dan kebanggaan serta nilai-nilai yang sama dengan FBLP, masing-masing mendapatkan persentase paling tinggi pada kategori sangat setuju yaitu 91,49\% untuk pernyataan kedekatan dan kebanggaan sebagai anggota FBLP dan 87,23\% untuk nilai-nilai yang sama dalam FBLP.

Kedua, integrasi ataukerjasama diukur dengan melihat keikutsertaan dalam setiap kegiatan FBLP, dan kepedulian terhadap sesama anggota FBLP. Secara lengkap dapat dilihat pada table 3 dibawah ini. 
Tabel 3 Jumlah dan persentase responden berdasarkan integrasi dan kerjasama di Serikat Buruh FBLP, 2020

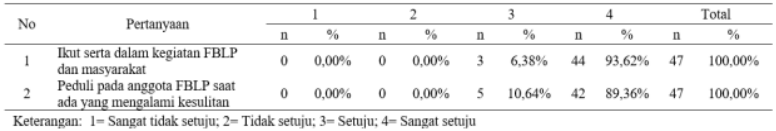

Berdasarkan tabel 3, terlihat bahwa responden ikut serta dalam kegiatan FBLP dan peduli pada sesama anggota yang mengalami kesulitan, masing-masing mendapatkan persentase paling tinggi pada kategori sangat setuju yaitu 93,62\% untuk pernyataan ikut serta dalam kegiatan FBLP dan 89,36\% untuk kepedulian pada sesama anggota FBLP saat ada yang mengalami kesulitan.

\section{Resiliensi Buruh Anggota FBLP}

Resiliensi merupakan mekanisme adaptasi untuk memperbaiki keadaan yang tidak stabil seperti dampak yang ditimbulkan ketika pandemi Covid-19. Secara umum resiliensi merupakan upaya untuk menyesuaikan diri dengan lingkungan yang berubah dengan mengandalkan potensi sumberdaya yang ada. Arbon et al., (2013) mengungkapkan bahwa resiliensi memiliki empat komponen, yaitu community connectedness (keterhubungan komunitas), risk and vulnerability (resiko dan kerentanan), planning and procedures (perencanaan dan prosedur), dan available resources (ketersediaan sumber daya).

Pada penelitian ini, community connectedness (keterhubungan komunitas) diukur untuk melihat kemampuan mengakses informasi, kemampuan untuk menghubungi sesama anggota FBLP, dan anggota diluar FBLP, serta kemampuan untuk mengakses dengan wilayah yang lebih luas. Berdasarkan empat pernyataan tersebut didapatkan hasil yang menunjukan keterhubungan komunitas dalam menghubungi sesama anggota FBLP mendapatkan persentase paling tinggi pada kategori sangat tinggi yaitu $80,85 \%$, namun sebaliknya kemampuan untuk berhubungan dengan wilayah yang lebih luas seperti pemerintah mendapatkan persentase paling rendah pada kategori sangat tinggi jika dibandingkan dengan tiga pernyataan lainnya, yaitu sebesar 38,30\%. Secara lengkap dapat dilihat pada tabel 4 dibawah ini.

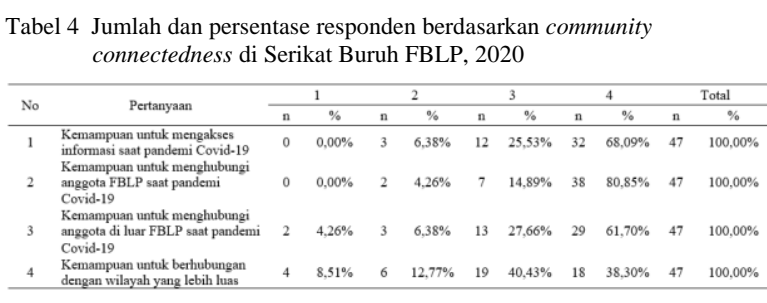

Selanjutnya pada risk and vulnerability (resiko dan kerentanan), diukur untuk melihat pengetahuan terhadap dampak pandemi Covid-19 dan kemampuan untuk beraktivitas secara normal setelah terjadi pandemi Covid-19. Berdasarkan dua pernyataan tersebut didapatkan hasil yang menunjukan bahwa pengetahuan terhadap dampak pandemi Covid-19 mendapatkan persentase paling tinggi pada kategori sangat tinggi yaitu 91,49\%, sebaliknya kemampuan untuk beraktivitas secara normal setelah terjadi pandemi Covid-19 mendapatkan persentase paling tinggi pada kategori sedang, yaitu sebesar 65,96\%. Secara lengkap dapat dilihat pada tabel 5 dibawah ini.

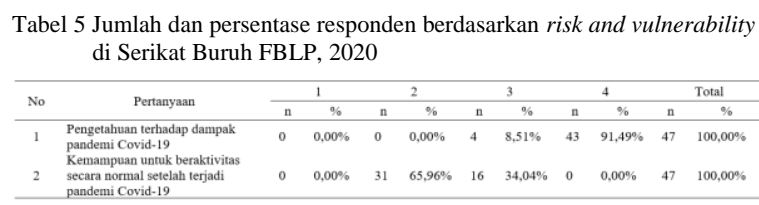

Kemudian pada planning and procedures (perencanaan dan prosedur), diukur untuk melihat pengetahuan mengenai respon tanggap dan pemulihan bencana, dan 
Keikutsertaan FBLP dalam kegiatan perencanaan tanggap darurat dan pemulihan pandemi Covid-19. Berdasarkan dua pernyataan tersebut didapatkan hasil yang menunjukan bahwa pengetahuan mengenai respon tanggap dan pemulihan bencana pandemi Covid-19 mendapatkan persentase paling tinggi pada kategori sangat tinggi yaitu $55,32 \%$. Pada pernyataan kedua terkait keikutsertaan FBLP dalam kegiatan perencanaan tanggap darurat dan pemulihan pandemi Covid-19 mendapatkan persentase paling tinggi pada kategori sangat tinggi, yaitu sebesar 59,57\%. Secara lengkap dapat dilihat pada tabel 6 dibawah ini.

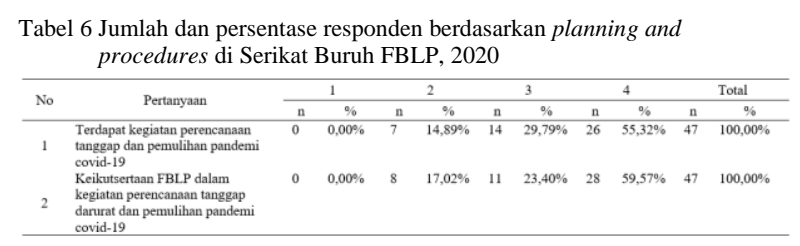

Terakhir, pada available resources (ketersediaan sumber daya), diukur untuk melihat pemenuhan kebutuhan pangan anggota FBLP saat pandemi Covid-19 dan kondisi fasilitas kesehatan saat pandemi Covid-19. Berdasarkan dua pernyataan tersebut didapatkan hasil yang menunjukan bahwa pemenuhan kebutuhan pangan anggota FBLP saat pandemi Covid-19 mendapatkan presentase paling besar pada kategori sangat tinggi dengan persentase $38,30 \%$, dan tinggi sebesar $25,53 \%$. Artinya jika digabungkan dua kategori tinggi dan sangat tinggi, maka didapatkan 63,83\% pemenuhan kebutuhan pangan anggota FBLP saat pandemi Covid-19 masuk dalam ketegori tinggi. Sedangkan untuk kondisi fasilitas kesehatan saat pandemi Covid-19 menunjukan bahwa $36,17 \%$ responden menyatakan dalam kondisi sangat baik dan $38,30 \%$ menyatakan dalam kondisi baik.
Secara lengkap dapat dilihat pada tabel 7 dibawah ini.

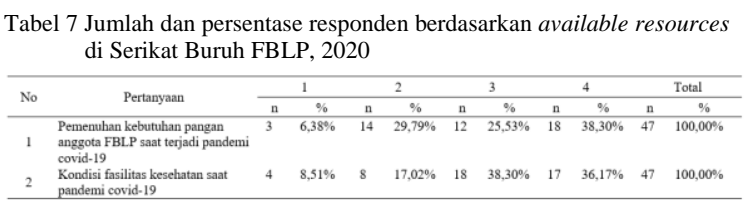

\section{PEMBAHASAN}

Fakta bahwa solidaritas sosial hadir dan menopang penyediaan kesejahteraan adalah bagian penting dari masyarakat (Shardlow \& Rochelle, 2017). Memberi penekanan pada fungsi, Alfirdaus, mengemukakan solidaritas sosial tidak dapat secara otomatis berfungsi karena masyarakat yang kompleks berdasarkan keadaan sosiologis, antropologis, dan politik mereka. Ada beberapa syarat yang diperlukan agar solidaritas sosial dapat bekerja. Karena itu, walaupun dalam beberapa kasus bencana solidaritas sosial menguat, berbagai hal dapat sangat berbeda di seluruh masyarakat atau disetiap komunitas. Dari sini, kita dapat melihat bagaimana solidaritas sosial dibangun berdasarkan karakteristik komunitas. Solidaritas sosial selama pandemi Covid-19 terjaga diantara para buruh karena antara buruh-serikat hidup dengan basis ketetanggaan dan kekerabatan (kinship) berlandaskan nilai yang sama, terlebih buruh tinggal pada komunitas yang sama. Nilai solidaritas sosial inilah yang akhirnya menumbuhkan tindakan kolektif untuk menghadapi ketidakpastian ditengah pandemi Covid-19.

Nilai solidaritas sosial yang tertanam (embedded) dalam tindakan aktor pada sistem ekonomi mampu mendorong tindakan kolektif pada aktor (buruh) dalam bentuk solidaritas sosial atau kesetiakawanan sosial. Solidaritas sosial yang terbentuk pada serikat buruh FBLP 
membuat buruh semakin peduli satu sama lain, sehingga dalam menghadapi berbagai keadaan dilakukan secara bersama-sama dengan adanya perasaan persatuan. Hal tersebut menunjukan bahwa solidaritas sosial memiliki pengaruh terhadap resiliensi buruh. Hal ini dibuktikan pada pengujian hipotesis yang menunjukan nilai signifikansi (Sig.) sebesar 0,000 $<0,01$ (probabilitas), sehingga dapat disimpulkan bahwa hipotesis diterima, yang artinya terdapat pengaruh signifikan solidaritas sosial terhadap resiliensi buruh ditengah pandemi Covid-19.

\begin{tabular}{|c|c|c|c|c|c|c|}
\hline \multicolumn{7}{|c|}{ Coefficients $^{2}$} \\
\hline \multirow{3}{*}{\multicolumn{2}{|c|}{ Model }} & \multirow{2}{*}{\multicolumn{2}{|c|}{ Unstandardized Coefficients }} & Standardized & \multirow[t]{3}{*}{$\mathrm{t}$} & \multirow[t]{3}{*}{ Sig. } \\
\hline & & & & Coefficients & & \\
\hline & & B & Std. Error & Beta & & \\
\hline \multirow[t]{2}{*}{1} & (Constant) & .234 & .241 & & .967 & .338 \\
\hline & Solidaritas & .865 & .088 & .825 & 9.810 & .000 \\
\hline
\end{tabular}

Bagi Durkheim, ketidakstabilan ekstrem memaksa masyarakat untuk membuat konsesi satu sama lain dan berbagi tanggung jawab, yang disebut solidaritas sosial, untuk mengembalikan situasi normal. Solidaritas sosial juga dipengaruhi interaksi sosial yang berlangsung karena ikatan kultural yang pada dasarnya disebabkan munculnya sentimen komunitas. Saling tolong menolong, berkerjasama, dan membantu selama pandemi Covid-19. Karena itu, walaupun dalam beberapa kasus bencana, solidaritas sosial mencul dan menguat, berbagai hal dapat sangat berbeda di seluruh masyarakat. Ada beberapa syarat yang diperlukan agar solidaritas sosial dapat bekerja, diantaranya melalui perasaan persatuan integrasi dan kerjasama.

Ketika intervensi pemerintah untuk memperingatkan dan menanggulangi pandemi Covid-19 atau untuk membantu pemulihan kesehatan dan ekonomi sebagian besar belum efektif, solidaritas sosial, pada gilirannya, mengambil alih peran dari negara. Hal ini menunjukan bahwa pandemi Covid-19 memberikan pemicu bagi tindakan sosial yang mungkin tidak hadir dalam kondisi non-pandemi. Dengan demikian, penting untuk membuka ruang alternatif bagaimana posisi dan peran masyarakat dalam lingkungan sosial dinegosiasikan dalam konteks struktur yang lebih besar (Hekmatyar \& Adinugraha, 2021). Solidaritas sosial memiliki makna yang lebih dalam ketika komunitas menghadapi musuh kolektif, sehingga memberi perasaan persatuan, bantuan, dan kohesi dalam keadaan sulit, sekaligus memberikan dasar bagi aksi kolektif buruh sesama anggota FBLP. Aksi kolektif tersebut, diantaranya diwujudkan dalam bentuk, 1) mediasi terhadap kebijakan PHK yang dilakukan perusahaan; 2) advokasi terhadap kebijakan PHK yang dilakukan perusahaan; 3) penggalangan bantuan untuk anggota yang mengalami PHK; 4) berbagi tempat tinggal dengan sesama anggota FBLP yang terkena PHK; dan 5) memberikan pinjaman untuk anggota yang mengalami PHK.

\section{KESIMPULAN}

Solidaritas sosial hadir sebagai upaya dari komunitas untuk meminimalisasi dampak bencana agar dapat kembali ke keadaan semula yang stabil. Solidaritas sosial yang tinggi terjaga karena antara buruh-serikat hidup dengan basis ketetanggaan dan persamaan nasib sebagai komunitas buruh di Kawasan Berikat Nusantara (KBN) Cakung. Solidaritas sosial juga dipengaruhi interaksi sosial yang berlangsung karena ikatan kultural yang pada dasarnya disebabkan munculnya sentimen komunitas. Nilai solidaritas sosial 
inilah yang akhirnya menumbuhkan tindakan kolektif untuk menghadapi ketidakpastian ditengah pandemi Covid-19. Nilai solidaritas sosial yang tertanam (embedded) dalam tindakan aktor dalam sistem ekonomi mampu mendorong tindakan kolektif pada aktor (buruh) dalam bentuk kesetiakawanan sosial. Tentu, komunitas tidak mengharapkan dampak negatif yang besar seperti krisis ekonomi akibat hilangnya sumber pendapatan mereka. Pengurangan dampak dari bencana dapat dilakukan, salah satunya adalah meningkatkan resiliensi komunitas. Tingkat solidaritas sosial dapat menjadi faktor keberhasilan dalam resiliensi terkait dengan integrasi buruh ke dalam sistem sosial komunitas, antara lain lingkungan sekitar, keluarga, jejaring kekerabatan, kohesivitas sosial, kepentingan bersama, dan kelompok swadaya, serta struktur yang disediakan oleh negara.

Penguatan komunitas sangat penting, bukan hanya pada saat pandemi Covid-19, tetapi juga dalam hal menangani, bertahan, dan pulih dari pandemi Covid-19. Penting juga untuk diperhatikan bahwa resiliensi rumah tangga akan tergantung pada berbagai tindakan dan kegiatan yang relatif kecil untuk membangun sumber daya, kesiapan, dan keterhubungan. Resiliensi buruh anggota FBLP diwujudkan dalam bentuk, 1) meminjam uang kepada sesama anggota FBLP; 2) menekan biaya konsumsi; 3) mencari sumber pendapatan lain; 4) pulang ke kampung halaman.

\section{DAFTAR PUSTAKA}

Alfirdaus, L. K. (2015). Theories of Social Solidarity in The Situations of (Natural) Disasters. Politika: Jurnal Ilmu Politik, 6(1), 44-70.

Arbon, P., Cusack, L., Gebbie, K.,
Steenkamp, M., \& Anikeeva, O. (2013). How do we measure and build resilience against disaster in communities and households.

Dombrowsky, W. R. (1983). Solidarity during snow-disasters. International Journal of Mass Emergencies and Disasters, 1(1), 189-205.

Gay, L. R., Mills, G. E., \& Airasian, P. (2012). Educational research: Competencies for analysis and applications (10 ed.). Pearson.

Ghafur, W. A., \& Gazali, H. (2012). Resilience perempuan dalam bencana alam merapi: Studi di Kinahrejo Umbulharjo Cangkringan Sleman Yogyakarta. WELFARE: Jurnal Ilmu Kesejahteraan Sosial, 1(1), 43-68.

Hekmatyar, V., \& Adinugraha, A. G. (2021). Ancaman Keberfungsian Sosial Pada Masyarakat Di Dalam Kawasan Konservasi: Studi Kasus Desa Ranupani Di Taman Nasional Bromo Tengger Semeru. BHUMI: Jurnal Agraria dan Pertanahan, 7(1), 28-41. https://doi.org/10.31292/bhumi.v7i1.46 4

International Labour Organization. (2020). Dalam menghadapi pandemi: Memastikan Keselamatan dan Kesehatan di Tempat Kerja. Labour Administration, Labour Inspection and Occupational Safety and Health Branch (LABADMIN/OSH) Route, 152.

https://www.ilo.org/wcmsp5/groups/pu blic/---asia/---ro-bangkok/---ilojakarta/documents/publication/wcms_7 42959.pdf

Johnson, D. P. (1986). Teori sosiologi klasik dan modern jilid 1. Gramedia Pustaka Utama.

Keputusan Presiden Republik Indonesia Nomor 11 Tahun 2020 Tentang Penetapan Kedaruratan Kesehatan Masyarakat Corona Virus Disease 2019 (Covid-19).

Keputusan Presiden Republik Indonesia Nomor 12 Tahun 2020 Tentang Penetapan Bencana Nonalam 
Penyebaran Corona Virus Disease 2019 (Covid-19) Sebagai Bencana Nasional.

Morgan, G., \& Pulignano, V. (2020). Solidarity at Work: Concepts, Levels and Challenges. Work, Employment and Society, 34(1), 18-34. https://doi.org/10.1177/0950017019866 626

Nasution, Z. (2009). Solidaritas sosial dan partisipasi masyarakat desa transisi: suatu tinjauan sosiologis. UMM Press.

Peraturan Pemerintah Republik Indonesia Nomor 21 Tahun 2020 Tentang Pembatasan Sosial Berskala Besar Dalam Rangka Percepatan Penanganan Corona Virus Disease 2019 (Covid19).

Shardlow, S. M., \& Rochelle, T. L. (2017). Social solidarity, social work and Chinese people. International Social Work, 60(4), 773-786. https://doi.org/10.1177/0020872814559 557

Singarimbun, M., \& Effendi, S. (1989). Metode penelitian survai. LP3es.

Undang-Undang Republik Indonesia Nomor 24 Tahun $2007 \quad$ Tentang Penanggulangan Bencana.

Van Breda, A. D. (2001). Resilience theory: A literature review. South African Military Health Service, Military Psychological Institute. Social Work Research \& Development. 